\title{
Intraoperative laser angiography using the SPY system: review of the literature and recommendations for use
}

\author{
Geoffrey C Gurtner ${ }^{1}$, Glyn E Jones ${ }^{2}$, Peter C Neligan ${ }^{3}$, Martin I Newman ${ }^{4}$, Brett T Phillips ${ }^{5}$, Justin M Sacks ${ }^{6}$ and \\ Michael R Zenn ${ }^{7 *}$
}

\begin{abstract}
Inadequate tissue perfusion is a key contributor to early complications following reconstructive procedures. Accurate and reliable intraoperative evaluation of tissue perfusion is critical to reduce complications and improve clinical outcomes. Clinical judgment is the most commonly used method for evaluating blood supply, but when used alone, is not always completely reliable. A variety of other methodologies have been evaluated, including Doppler devices, tissue oximetry, and fluorescein, among others. However, none have achieved widespread acceptance. Recently, intraoperative laser angiography using indocyanine green was introduced to reconstructive surgery. This vascular imaging technology provides real-time assessment of tissue perfusion that correlates with clinical outcomes and can be used to guide surgical decision making. Although this technology has been used for decades in other areas, surgeons may not be aware of its utility for perfusion assessment in reconstructive surgery. A group of experts with extensive experience with intraoperative laser angiography convened to identify key issues in perfusion assessment, review available methodologies, and produce initial recommendations for the use of this technology in reconstructive procedures.
\end{abstract}

Keywords: SPY, Indocyanine green, Laser angiography, Reconstructive surgery, Perfusion assessment, Flap, Near infrared, Necrosis, Flap, Microsurgery

\section{Introduction}

One of the fundamental causes of early complications following reconstructive procedures is considered to be inadequate tissue perfusion [1-6]. Therefore, accurate and reliable intraoperative evaluation of tissue perfusion is critical to reduce complications and improve clinical outcomes. Clinical judgment is the most widely used method for evaluating blood supply [7], but by itself is not always completely reliable for assessment of flap perfusion $[8,9]$. Several technologies to assess tissue vascularity have been evaluated in studies and used clinically, but none have achieved universal acceptance $[6,10]$.

Intraoperative laser angiography using indocyanine green (ICG) is a vascular imaging methodology that can be used in the intraoperative or postoperative setting to

\footnotetext{
* Correspondence: michael.zenn@duke.edu

${ }^{7}$ Plastic and Reconstructive Surgery, Duke University Medical Center, Durham, NC, USA

Full list of author information is available at the end of the article
}

visually assess superficial blood flow. Characteristics of ICG angiography make it a desirable option for tissue evaluation. The technique provides real-time assessment of tissue perfusion that has been correlated with clinical outcomes $[1,5,6,11,12]$ and guides surgical decision making, such as flap design or intraoperative tissue resection [13]. ICG has an excellent safety profile and short plasma half-life, allowing for repeat evaluations during the same operative procedure. Although this technology has been used for decades in ophthalmology, its introduction to reconstructive surgery is relatively recent, and surgeons may not be aware of its characteristics, indications in reconstructive surgeries, and best practices in the intraoperative setting.

In May of 2011, a group of 7 experts (6 plastic surgeons and 1 general surgery resident) with extensive experience in the use of SPY Intraoperative Perfusion Assessment System (distributed in North America by LifeCell Corp., Branchburg, Nj; manufactured by Novadaq

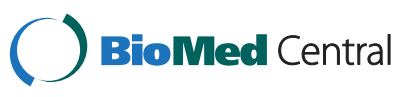


Table 1 Methods for evaluation of tissue perfusion, by setting

\begin{tabular}{|c|c|c|c|c|}
\hline Method/Setting & use & Advantages & Limitations & Sources \\
\hline \multicolumn{5}{|l|}{ Intraoperative } \\
\hline \multirow[t]{14}{*}{$\begin{array}{l}\text { ICG intraoperative } \\
\text { laser angiography* }\end{array}$} & $\begin{array}{l}\rightarrow \text { Visualize perforator } \\
\text { perfusion zone in real time }\end{array}$ & $\begin{array}{l}\rightarrow \text { Visualizes perforator } \\
\text { perfusion zones }\end{array}$ & $\begin{array}{l}\rightarrow \text { Requires administration } \\
\text { of contrast media }\end{array}$ & $\begin{array}{l}\text { Phillips et al., } \\
2012 \text { [12] }\end{array}$ \\
\hline & $\begin{array}{l}\rightarrow \text { Confirm patency of arterial } \\
\text { and venous anastomoses }\end{array}$ & $\begin{array}{l}\rightarrow \text { No exposure to } \\
\text { ionizing radiation }\end{array}$ & \multirow{13}{*}{$\begin{array}{l}\rightarrow \text { Does not identify precise } \\
\text { vessel location or course through } \\
\text { muscle and fascia when lipodystrophy } \\
\text { exists }\end{array}$} & $\begin{array}{l}\text { Francisco et al., } \\
2010[52]\end{array}$ \\
\hline & \multirow[t]{12}{*}{$\begin{array}{l}\rightarrow \text { Confirm perfusion of tissue } \\
\text { prior to incision, after elevation } \\
\text { of flaps, and prior to final closure }\end{array}$} & $\begin{array}{l}\rightarrow \text { Strong safety profile } \\
\text { and short half-life of ICG }\end{array}$ & & $\begin{array}{l}\text { Komorowska- } \\
\text { Timek \& Gurtner, } \\
2010[1]\end{array}$ \\
\hline & & $\begin{array}{l}\rightarrow \text { Permits re-evaluation } \\
\text { during same surgery }\end{array}$ & & $\begin{array}{l}\text { Murray et al., } \\
2010[16]\end{array}$ \\
\hline & & & & $\begin{array}{l}\text { Tamburrino et al., } \\
2010[17]\end{array}$ \\
\hline & & & & $\begin{array}{l}\text { Newman et al., } \\
2009 \text { [11] }\end{array}$ \\
\hline & & & & $\begin{array}{l}\text { Jones et al., } \\
2009[14]\end{array}$ \\
\hline & & & & $\begin{array}{l}\text { Azuma et al., } \\
2008 \text { [18] }\end{array}$ \\
\hline & & & & $\begin{array}{l}\text { Prantl et al., } \\
2008[19]\end{array}$ \\
\hline & & & & $\begin{array}{l}\text { De Lorenzi et al., } \\
2005 \text { [20] }\end{array}$ \\
\hline & & & & $\begin{array}{l}\text { Mothes et al., } \\
2004 \text { [8] }\end{array}$ \\
\hline & & & & $\begin{array}{l}\text { Holm, Tegeler, } \\
\text { et al., } 2002 \text { [21] }\end{array}$ \\
\hline & & & & $\begin{array}{l}\text { Holm, Mayr, et al., } \\
2002[22]\end{array}$ \\
\hline & & & & $\begin{array}{l}\text { Still et al. } 1999 \\
\text { [23] }\end{array}$ \\
\hline \multirow[t]{7}{*}{ Doppler - handheld } & \multirow[t]{7}{*}{$\begin{array}{l}\rightarrow \text { dentification of } \\
\text { perforator vessel location }\end{array}$} & $\rightarrow$ Easy to use & $\begin{array}{l}\rightarrow \text { Provides information on } \\
\text { discrete area below probe }\end{array}$ & \multirow[t]{7}{*}{$\begin{array}{l}\text { Yu \& Youssef, } \\
2006[29]\end{array}$} \\
\hline & & $\rightarrow$ Widely available & $\rightarrow$ Requires direct skin contact & \\
\hline & & $\rightarrow$ Inexpensive & $\begin{array}{l}\rightarrow \text { Does not identify perforator } \\
\text { perfusion zone }\end{array}$ & \\
\hline & & \multirow[t]{4}{*}{$\begin{array}{l}\rightarrow \text { Provides confirmatory } \\
\text { information }\end{array}$} & $\begin{array}{l}\rightarrow \text { Provides limited data and accuracy } \\
\text { for flap design, }\end{array}$ & \\
\hline & & & $\rightarrow$ especially in heavier patients & \\
\hline & & & $\rightarrow$ Difficult to quantify & \\
\hline & & & $\rightarrow$ Does not stratify perforators & \\
\hline \multirow[t]{6}{*}{ Fluorescein } & \multirow[t]{6}{*}{$\begin{array}{l}\rightarrow \text { Visualization of } \\
\text { perforator perfusion zone }\end{array}$} & $\begin{array}{l}\rightarrow \text { Visualization of } \\
\text { perforator perfusion zone }\end{array}$ & $\rightarrow$ Single use only & $\begin{array}{l}\text { Phillips et al., } \\
2012 \text { [12] }\end{array}$ \\
\hline & & \multirow[t]{5}{*}{$\rightarrow$ Widely available } & $\rightarrow$ No venous information & \multirow{5}{*}{$\begin{array}{l}\text { Losken et al., } \\
2008[51]\end{array}$} \\
\hline & & & $\rightarrow$ Long delay time & \\
\hline & & & $\rightarrow$ Toxicity concerns & \\
\hline & & & $\rightarrow$ Use of ultraviolet Woods lamp & \\
\hline & & & $\rightarrow$ High sensitivity, low specificity & \\
\hline \multicolumn{5}{|l|}{ Preoperative } \\
\hline \multirow[t]{3}{*}{ Clinical judgment } & \multirow[t]{3}{*}{$\begin{array}{l}\rightarrow \text { Estimation of tissue } \\
\text { perfusion and flap viability }\end{array}$} & \multirow[t]{3}{*}{$\rightarrow$ Familiarity, ease of use } & $\rightarrow$ Poor reliability when used alone & $\begin{array}{l}\text { Phillips et al., } \\
2012 \text { [12] }\end{array}$ \\
\hline & & & $\rightarrow$ Dependent on surgeon experience & $\begin{array}{l}\text { Mothes et al., } \\
2004[8]\end{array}$ \\
\hline & & & $\begin{array}{l}\rightarrow \text { Inferior to imaging modalities } \\
\text { for estimation of flap survival }\end{array}$ & $\begin{array}{l}\text { Olivier et al., } \\
2003[9]\end{array}$ \\
\hline
\end{tabular}


Table 1 Methods for evaluation of tissue perfusion, by setting (Continued)

\begin{tabular}{|c|c|c|c|c|}
\hline & & & & $\begin{array}{l}\text { Holm, Tegeler } \\
\text { et al., } 2002 \text { [21] }\end{array}$ \\
\hline \multirow{5}{*}{$\begin{array}{l}\text { Doppler Ultrasound } \\
\text { (duplex, color, } \\
\text { power) }\end{array}$} & $\begin{array}{l}\rightarrow \text { dentification of } \\
\text { perforator vessel location }\end{array}$ & $\begin{array}{l}\rightarrow \text { No exposure to ionizing } \\
\text { radiation or contrast media }\end{array}$ & $\begin{array}{l}\rightarrow \text { Inferior to CT angiography for } \\
\text { identification of vessel location }\end{array}$ & $\begin{array}{l}\text { Rozen et al., } \\
2008[24]\end{array}$ \\
\hline & \multirow[t]{4}{*}{$\rightarrow$ Estimate of vessel flow rate } & \multirow{4}{*}{$\begin{array}{l}\rightarrow \text { Provides estimation of } \\
\text { perforator location, caliber, } \\
\text { and flow }\end{array}$} & $\rightarrow$ Considered operator-dependent & $\begin{array}{l}\text { Khalid et al., } \\
2006[25]\end{array}$ \\
\hline & & & $\begin{array}{l}\rightarrow \text { Does not identify perforator } \\
\text { perfusion zone }\end{array}$ & $\begin{array}{l}\text { Giunta et al., } \\
2000[26]\end{array}$ \\
\hline & & & \multirow{2}{*}{$\begin{array}{l}\rightarrow \text { High rate of false-positive } \\
\text { findings reported }\end{array}$} & Hallock, 2003 [27] \\
\hline & & & & $\begin{array}{l}\text { Blondeel et al., } \\
1998[28]\end{array}$ \\
\hline \multirow[t]{4}{*}{$\begin{array}{l}\text { Laser Doppler } \\
\text { flowmetry }\end{array}$} & \multirow[t]{4}{*}{$\begin{array}{l}\rightarrow \text { dentification of vessel } \\
\text { location and tissue perfusion }\end{array}$} & $\begin{array}{l}\rightarrow \text { No exposure to ionizing } \\
\text { radiation or contrast media }\end{array}$ & $\rightarrow$ May underestimate flap survival & $\begin{array}{l}\text { Schlosser et al., } \\
2010[30]\end{array}$ \\
\hline & & $\rightarrow$ dentifies ischemia in flaps & $\begin{array}{l}\rightarrow \text { Poor ability to detect } \\
\text { perforator vessels }\end{array}$ & $\begin{array}{l}\text { Holzle et al., } \\
2006[31]\end{array}$ \\
\hline & & & $\rightarrow$ Sensitive to small movements & $\begin{array}{l}\text { Heller et al., } \\
2001[32]\end{array}$ \\
\hline & & & & $\begin{array}{l}\text { Heden et al. } \\
1986 \text { [33] }\end{array}$ \\
\hline \multirow[t]{8}{*}{ CT angiography } & \multirow[t]{8}{*}{$\begin{array}{l}\rightarrow \text { Visualization of location and } \\
\text { course of vessels through muscles } \\
\text { and fascia }\end{array}$} & $\begin{array}{l}\rightarrow \text { Accurate detection of } \\
\text { anatomic location and course } \\
\text { of vessels }\end{array}$ & $\rightarrow$ Does not assess vascular flow & $\begin{array}{l}\text { Ghattaura } \\
\text { et al.,2010 [34] }\end{array}$ \\
\hline & & $\begin{array}{l}\rightarrow \text { Greater accuracy than } \\
\text { Doppler ultrasound }\end{array}$ & $\begin{array}{l}\rightarrow \text { Does not show perforator } \\
\text { perfusion zones }\end{array}$ & $\begin{array}{l}\text { Smit et al., } 2009 \\
\text { [35] }\end{array}$ \\
\hline & & $\begin{array}{l}\rightarrow \text { Potential for reduced } \\
\text { surgical time }\end{array}$ & $\begin{array}{l}\rightarrow \text { May have poor resolution for } \\
\text { vessel caliber; }\end{array}$ & $\begin{array}{l}\text { Rozen et al., } \\
2008 \text { [24] }\end{array}$ \\
\hline & & & $\rightarrow$ Exposure to ionizing radiation & $\begin{array}{l}\text { Cina et al., } 2010 \\
{[36]}\end{array}$ \\
\hline & & & $\rightarrow$ Potential toxicity of contrast media & $\begin{array}{l}\text { Scott et al., } 2010 \\
\text { [37] }\end{array}$ \\
\hline & & & & $\begin{array}{l}\text { Phillips et al., } \\
2008 \text { [38] }\end{array}$ \\
\hline & & & & $\begin{array}{l}\text { Rosson et al., } \\
2007 \text { [39] }\end{array}$ \\
\hline & & & & $\begin{array}{l}\text { Masia et al., } \\
2006[40]\end{array}$ \\
\hline \multirow[t]{6}{*}{ MR angiography } & \multirow{6}{*}{$\begin{array}{l}\rightarrow \text { Visualization of location and } \\
\text { course of vessels through muscles } \\
\text { and fascia }\end{array}$} & $\begin{array}{l}\rightarrow \text { Greater accuracy than } \\
\text { Doppler ultrasound }\end{array}$ & $\rightarrow$ Does not assess vascular flow & $\begin{array}{l}\text { Schaverien et al., } \\
2011[42]\end{array}$ \\
\hline & & $\begin{array}{l}\rightarrow \text { Detection of small caliber } \\
\text { vessels }\end{array}$ & $\begin{array}{l}\rightarrow \text { Does not show perforator } \\
\text { perfusion zones }\end{array}$ & $\begin{array}{l}\text { Newman et al., } \\
2010 \text { [43] }\end{array}$ \\
\hline & & $\begin{array}{l}\rightarrow \text { Potential for reduced } \\
\text { surgical time }\end{array}$ & $\begin{array}{l}\rightarrow \text { Less spatial resolution compared } \\
\text { to CT angiography }\end{array}$ & $\begin{array}{l}\text { Greenspun } \\
\text { et al., } 2010 \text { [45] }\end{array}$ \\
\hline & & $\rightarrow$ No exposure to ionizing & $\rightarrow$ Potential toxicity of contrast & $\begin{array}{l}\text { Chernyak et al., } \\
2009 \text { [41] }\end{array}$ \\
\hline & & $\rightarrow$ radiation & $\rightarrow$ media & $\begin{array}{l}\text { Neil-Dwyer } \\
\text { et al., } 2009 \text { [44] }\end{array}$ \\
\hline & & & & $\begin{array}{l}\text { Rozen et al., } \\
2009[46]\end{array}$ \\
\hline \multicolumn{5}{|l|}{ Postoperative } \\
\hline \multirow[t]{2}{*}{$\begin{array}{l}\text { Transcutaneous } \\
\text { oxygen monitoring** }\end{array}$} & \multirow[t]{2}{*}{$\begin{array}{l}\rightarrow \text { Assessment of tissue } \\
\text { oxygen saturation }\end{array}$} & $\begin{array}{l}\rightarrow \text { Useful for postoperative } \\
\text { monitoring }\end{array}$ & $\begin{array}{l}\rightarrow \text { Limited to discrete } 1 \mathrm{~cm}^{2} \text { area } \\
\text { under probe }\end{array}$ & Steele, 2011 [47] \\
\hline & & $\begin{array}{l}\rightarrow \text { Accurately detects } \\
\text { vascular compromise }\end{array}$ & $\rightarrow$ Numeric output only & $\begin{array}{l}\text { Lin et al., } 2011 \\
\text { [48] }\end{array}$ \\
\hline
\end{tabular}




\section{Table 1 Methods for evaluation of tissue perfusion, by setting (Continued)}

\begin{tabular}{|c|c|c|c|}
\hline & $\begin{array}{l}\rightarrow \text { Improves flap salvage } \\
\text { rate in postoperative setting }\end{array}$ & $\begin{array}{l}\rightarrow \text { Used primarily for } \\
\text { postoperative monitoring }\end{array}$ & Keller, 2009 [49] \\
\hline & & $\begin{array}{l}\rightarrow \text { Time consuming, cumbersome } \\
\text { for intraoperative mapping }\end{array}$ & Keller, 2007 [50] \\
\hline
\end{tabular}

Technologies Inc., Richmond, British Columbia, Canada) convened a summit to develop a review describing the current state of the art of evaluation of tissue perfusion in reconstructive surgery. All of the authors use the SPY System, which has received FDA clearance for use in cardiovascular procedures; plastic, micro- and reconstructive surgical procedures; organ transplant; and gastrointestinal surgical procedures. The goals of this summit were to describe clinical uses for the SPY System in reconstructive surgical procedures and to produce a set of technical recommendations for its use. An extensive literature review was conducted to identify relevant studies, and the

Table 2 Clinical evidence of utility the SPY system, by application

\begin{tabular}{|c|c|c|c|}
\hline Authors & Study design & Applications studied & Key points \\
\hline \multicolumn{4}{|l|}{ Free flaps } \\
\hline \multirow{2}{*}{$\begin{array}{l}\text { Pestana et al., } \\
2009[5]\end{array}$} & Case series & \multirow{2}{*}{$\begin{array}{l}\text { Multiple indications: head and } \\
\text { neck, breast, lower extremity }\end{array}$} & \multirow[t]{2}{*}{1 partial flap loss } \\
\hline & $\begin{array}{l}\mathrm{N}=27 \text { patients, } 29 \text { free } \\
\text { tissue transfers }\end{array}$ & & \\
\hline \multicolumn{4}{|l|}{$\begin{array}{l}\text { Breast recon- } \\
\text { struction }\end{array}$} \\
\hline \multirow[t]{2}{*}{$\begin{array}{l}\text { Phillips et al., } \\
2012 \text { [12] }\end{array}$} & $\begin{array}{l}\text { Prospective study } \\
\text { comparing ICG to } \\
\text { fluorescein and clinical } \\
\text { judgment }\end{array}$ & \multirow[t]{2}{*}{$\begin{array}{l}\text { Tissue expander-implant } \\
\text { breast reconstruction }\end{array}$} & \multirow[t]{2}{*}{$\begin{array}{l}\text { ICG and fluorescein had sensitivity of } 90 \% \text { and specificity of } \\
50 \% \text { and } 30 \% \text {, respectively; negative predictive value for ICG } \\
\text { and fluorescein was } 88 \% \text { and } 82 \% \text {, respectively. }\end{array}$} \\
\hline & $\begin{array}{l}\mathrm{N}=32 \text { patients, } \\
51 \text { breasts }\end{array}$ & & \\
\hline \multirow{2}{*}{$\begin{array}{l}\text { Newman et al., } \\
2011[6]\end{array}$} & Case series & \multirow{2}{*}{$\begin{array}{l}\text { Breast reconstruction: } \\
\text { single-pedicle TRAM }\end{array}$} & \multirow{2}{*}{$\begin{array}{l}\text { ICG perfusion assessment identified perfusion zones; no } \\
\text { issues with wound healing or tissue or fat necrosis. }\end{array}$} \\
\hline & $N=20$ & & \\
\hline \multirow{2}{*}{$\begin{array}{l}\text { Komorowska- } \\
\text { Timek and } \\
\text { Gurtner, } 2010[1]\end{array}$} & Case series & \multirow{2}{*}{$\begin{array}{l}\text { Breast reconstruction: tissue } \\
\text { expander, latissimus dorsi } \\
\text { flaps, DIEP/SIEA }\end{array}$} & \multirow{2}{*}{$\begin{array}{l}\text { Tissue expander }(n=16) \text {, latissimus dorsi }(n=2) \text {, DIEP/SIEA } \\
(n=6) \text {; complication rate: } 4 \% \text { with ICG vs. } 15.1 \% \text { in } 206 \\
\text { previous reconstructions ( } n=148 ; p<0.01)\end{array}$} \\
\hline & $\mathrm{N}=20$ patients, 24 breasts & & \\
\hline \multirow{3}{*}{$\begin{array}{l}\text { Tamburrino } \\
\text { et al., } 2010 \text { [17] }\end{array}$} & Retrospective analysis & \multirow{3}{*}{$\begin{array}{l}\text { Breast reconstruction: tissue } \\
\text { expander or unilateral TRAM }\end{array}$} & \multirow{3}{*}{$\begin{array}{l}\text { 95\% correlation between ICG imaging and clinical } \\
\text { outcome, 100\% sensitivity and 91\% specificity. }\end{array}$} \\
\hline & $\begin{array}{l}\text { Tissue expander } \\
(\mathrm{n}=11 \text { patients, } \\
19 \text { breasts })\end{array}$ & & \\
\hline & Unilateral TRAM $(n=1)$ & & \\
\hline $\begin{array}{l}\text { Francisco et al., } \\
2010 \text { [52] }\end{array}$ & Case series $\mathrm{N}=5$ & Breast reconstruction: DIEP & No flap loss, fat necrosis, or take-backs \\
\hline \multirow{2}{*}{$\begin{array}{l}\text { Jones et al., } \\
2009[14]\end{array}$} & Case series & \multirow{2}{*}{$\begin{array}{l}\text { Breast reconstruction: free and } \\
\text { pedicle TRAM, DIEP, latissimus dorsi, } \\
\text { and expander insertions. }\end{array}$} & \multirow{2}{*}{$\begin{array}{l}\text { Of } 5 \text { patients with poor flap perfusion on ICG imaging, } 4 \\
\text { developed necrosis and } 1 \text { blistering in a pattern predicted } \\
\text { by ICG; necrosis rate of } 6.3 \% \text { vs. published rates of } 15-25 \% \text {. }\end{array}$} \\
\hline & $\mathrm{N}=43$ patients, 64 breasts & & \\
\hline \multirow{2}{*}{$\begin{array}{l}\text { Newman \& } \\
\text { Samson, } 2009 \text { [11] }\end{array}$} & Case series & \multirow{2}{*}{$\begin{array}{l}\text { Breast reconstruction: DIEP or } \\
\text { free TRAM }\end{array}$} & \multirow{2}{*}{$\begin{array}{l}\text { ICG detected marginal or poor perfusion in } 4 \text { cases; } 3 \text { were } \\
\text { revised intraoperatively and the } 1 \text { that was not revised } \\
\text { required return to OR for venous congestion. Flap survival } \\
\text { was } 100 \% \text {. }\end{array}$} \\
\hline & $\mathrm{N}=8$ patients, 10 breasts & & \\
\hline \multicolumn{4}{|l|}{ NAC evaluation } \\
\hline \multirow{2}{*}{$\begin{array}{l}\text { Murray et al., } \\
2010[16]\end{array}$} & Case series & \multirow[t]{2}{*}{ Breast reduction surgery } & \multirow{2}{*}{$\begin{array}{l}\text { ICG used to demonstrate NAC perfusion and venous outflow } \\
\text { during surgery. }\end{array}$} \\
\hline & $\mathrm{N}=12$ patients, 22 breasts & & \\
\hline
\end{tabular}

DIEP: deep inferior epigastric perforator.

$N A C$ : nipple-areolar complex.

SIEA: superficial inferior epigastric artery flap.

TRAM: transverse abdominus musculocutaneous. 
Table 3 Overall recommendations regarding use of the SPY System in reconstructive procedures, by flap type

\begin{tabular}{ll}
\hline Application & Points of use for ICG intraoperative laser angiography \\
\hline Free flaps & $\begin{array}{l}\text { 1. Identify perforator perfusion zone in donor site prior to } \\
\text { incision; select optimal perforator and design flap }\end{array}$ \\
\cline { 2 - 2 } & $\begin{array}{l}\text { 2. Confirm flap perfusion during dissection, testing and } \\
\text { comparing different perforators }\end{array}$ \\
& $\begin{array}{l}\text { 3. Confirm flap perfusion after transfer } \\
\text { 4. Confirm patency of arterial and venous anastomoses }\end{array}$ \\
& $\begin{array}{l}\text { 5. Detect areas of venous congestion by re-imaging 5- } \\
\text { 20 min after administration of ICG; can be performed } \\
\text { following flap dissection, transfer, and/or inset }\end{array}$ \\
\hline $\begin{array}{l}\text { Pedicle flap Identify perforator perfusion zone in donor site prior to } \\
\text { incision; design flap }\end{array}$ \\
$\begin{array}{l}\text { 2. Evaluate arterial and venous perfusion after elevation } \\
\text { of flap and prior to transfer }\end{array}$ \\
$\begin{array}{l}\text { 3. After transfer and after inset, confirm arterial inflow and } \\
\text { venous return }\end{array}$ \\
\hline $\begin{array}{l}\text { Skin flap Evaluate perfusion prior to incision; design flap } \\
\text { 2. After dissection, confirm flap perfusion }\end{array}$ \\
\begin{tabular}{l} 
3. After transfer and inset, confirm perfusion of flap \\
\hline Mastectomy
\end{tabular} \\
$\begin{array}{l}\text { 1. Following mastectomy, confirm integrity of vascular } \\
\text { perfusion in mastectomy flaps; select delayed vs. } \\
\text { immediate reconstruction; select implant vs. expander } \\
\text { reconstruction }\end{array}$ \\
$\begin{array}{l}\text { 2. Confirm perfusion after insertion of reconstructive } \\
\text { modality; determine expander volume or implant size; } \\
\text { determine skin paddle size }\end{array}$ \\
\hline If revisions made, confirm perfusion in flaps \\
\hline
\end{tabular}

recommendations described in this review are based on the best available evidence.

\section{Background}

Dissection of tissue of any kind is accompanied by some degree of devascularization, and accurate determination of tissue viability is critical to all surgeons. Loss of skin flaps due to ischemia and postoperative necrosis can be catastrophic and may result in an even larger tissue deficit requiring repair. Early identification of insufficiently perfused tissue with the potential to develop ischemia or postoperative necrosis will help guide intraoperative decision making, such as the need for flap revision, tissue resection, or a delayed procedure.

The wide variation in anatomic location of perforating vessels and their perfusion zones makes vessel selection and flap design a clinical challenge. Therefore, a reliable method to identify perforating vessels and their perfusion zones, assess tissue perfusion, and identify tissue at risk for necrosis would be valuable to surgeons. Clinical judgment alone remains the most commonly used intraoperative method to determine the degree of tissue perfusion [7]. Although clinical judgment is an important tool and provides relevant information, studies have demonstrated that clinical assessment alone can at times be a poor predictor of postoperative complications $[8,9,12]$.

The SPY System provides a clinically useful assessment of perfusion in a variety of applications, including free and pedicle flaps and mastectomy and other skin flaps [14]. The technique allows for visualization of arterial inflow, venous return, and tissue perfusion during the intraoperative period. The information provided by this technique augments and strengthens clinical judgment and provides the surgeon with real-time visualization of tissue perfusion and vascular changes that result from surgical maneuvers.

The SPY System utilizes a fluorescence agent, indocyanine green (ICG), to enable visualization, similar to fluorescein in the past. Certain characteristics of ICG make it a more beneficial tool for intraoperative perfusion assessment. The ICG molecule binds strongly to plasma proteins, causing it to remain in the intravascular space. It also has a short plasma half-life of 3 to 5 minutes in humans [15]. This pharmacokinetic profile allows for rapid clearance of dye from tissues and repeated evaluations during the same surgical procedure. In comparison, the dye fluorescein stays in the tissue for more than 12 hours, meaning that it can be used only once. ICG is administered by means of peripheral or central intravenous access, is excreted exclusively by the liver into the bile, and is not associated with risk for nephrotoxicity. The laser diode array utilized by the SPY System emits a nearinfrared wavelength that does not require the use of protective eyewear or other safety equipment.

The SPY System is currently indicated for capturing and viewing fluorescence images for the visual assessment of blood flow as an adjunctive method for the evaluation of tissue perfusion and related tissue-transfer circulation in tissue and free flaps used in plastic, micro-, and reconstructive and gastrointestinal surgical procedures. The system is used in evaluating recipient site vascularity as well as circulation in tissue flaps and free flaps used in plastic, microsurgical, and reconstructive surgical procedures [15]. For plastic and reconstructive surgery applications, the SPY System can be used to evaluate perfusion in all components of the flap, including skin, fat, fascia, muscle, periosteum, nipple (in breast reconstruction, reduction, and mastopexy), and arterial and venous flow in vessels (in microsurgery).

The recommendations and the authors' personal experiences pertain to the SPY Intraoperative Perfusion Assessment System. This system utilizes a laser diode array to illuminate a maximum field of $18.5 \times 13.5 \mathrm{~cm}^{2}$ [15]. A charge-coupled device camera can be configured to capture image sequences at 3.75 to 30 frames per second, depending on the desired recording time of between 30 seconds and up to a maximum of 4.5 minutes. Images are viewed on a high-definition monitor in real time, allowing for 
Table 4 Technical recommendations for use of the SPY System

\begin{tabular}{ll}
\hline Application & Timing of evaluation* \\
\hline Microvascular reconstructive surgery & $15-30 \mathrm{sec}$ \\
\hline Pre-incision identification of perforators & $1-2$ min \\
\hline Following dissection, confirmation of adequate flow and limits of perfusion & Arterial phase: instantaneous. \\
\hline Following transfer, evaluation of arterial and venous anastomoses & Venous phase: $30-60$ sec \\
\cline { 2 - 2 } & Re-image at 2 min; if venous congestion is \\
& suspected, evaluate again at $\geq 4$ min \\
\hline Following inset, confirmation of adequate flow and limits of perfusion & $1-2$ min (Wait at least 10 min following previous \\
\hline Pedicle flap reconstruction & ICG administration) \\
\hline Pre-incision identification of perforator perfusion zone & \\
\hline $\begin{array}{l}\text { Following elevation of flap, confirmation of adequate flow and limits of perfusion } \\
\text { (selection of skin and soft tissue for preservation) }\end{array}$ & 1 min \\
\hline Following transposition and inset, confirmation of adequate flow and limits of perfusion & $1-2$ min \\
\hline Skin flap reconstruction** & \\
\hline Following elevation of skin flap, define limits of perfusion for flap design and detect \\
sub-clinical ischemia
\end{tabular}

\section{Mastectomy followed by TE/I reconstruction}

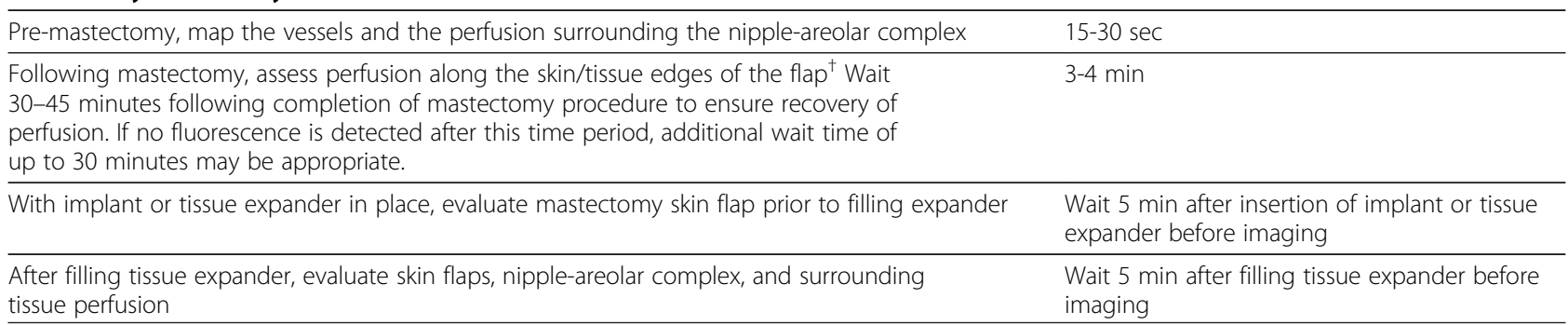
tissue perfusion

$T E / I=$ tissue expander/implant.

* Start recording after first appearance of fluorescent blush. Times given indicate when within the captured image sequence assessments should be made. **For areas or conditions associated with reduced perfusion (eg, lower extremities, vasculopathy), longer wait times may be required before evaluation. Notes: The Instructions for Use supplied with SPY note that the $25 \mathrm{mg}$ ICG should be reconstituted in $10 \mathrm{cc}$ of normal saline, giving a concentration of $2.5 \mathrm{mg} / \mathrm{cc}$ [15]. The Instructions for Use suggest administration of $10 \mathrm{mg}$ (or $4 \mathrm{cc}$ ) ICG for visualization of tissue perfusion. For restudy, wait $\geq 10$ min from previous injection of ICG. Take a baseline image before restudy to ensure that ICG has washed out. If complete wash out is needed, wait 15 minutes from previous ICG administration.

immediate evaluation in the OR. The system includes computer hardware and software for capturing, enhancing visualization, and archiving of images and creation and printing of imaging procedure reports [11]. A companion post-processing software product (SPY- $\mathrm{Q}^{\mathrm{Tx}}$ Analysis Toolkit) provides additional viewing, comparison, and analysis tools, including algorithms for measurement of fluorescence intensity. The clinician retains ultimate responsibility for making the pertinent diagnosis based on their standard clinical practices and visual comparison of the images.

\section{Modalities for assessment of tissue perfusion}

Clinical judgment for flap evaluation involves subjective indices, such as tissue color, capillary refill, flap temperature, and dermal bleeding. When used alone, even by experienced surgeons, clinical judgment may inaccurately assess adequacy of tissue perfusion and predict ultimate outcomes.

Surgeons have evaluated and incorporated adjunctive modalities for assessment of vascular anatomy and, in some cases, tissue perfusion. Multiple modalities have been used clinically and described in the literature, including various Doppler devices, computed tomography angiography (CTA), magnetic resonance angiography (MRA), tissue oximetry, and fluorescein, among others (Table 1) [1,8,9,11,12,14,16-52].

Intraoperative use of hand-held Doppler is safe, simple, and widely available. Several authors have described the preoperative use of Doppler ultrasound to identify vessel location $[27,28]$. However, the technique is considered an operator-dependent procedure [27], does not identify the perforator perfusion zone, and provides limited information and accuracy for flap design [29]. Evidence suggests 
Table 5 Examples of flap types and procedures appropriate for imaging with ICG intraoperative laser angiography

\begin{tabular}{|c|c|}
\hline \multirow{15}{*}{$\begin{array}{l}\text { Mastectomy and other } \\
\text { skin flaps }\end{array}$} & Mastectomy flaps \\
\hline & Cervicofacial flaps \\
\hline & Facelift \\
\hline & Cheek flap \\
\hline & Cervical advancement flap \\
\hline & Forehead flap \\
\hline & Skin flap over pectoralis major \\
\hline & Degloving injuries, upper and lower extremity \\
\hline & Abdominal flaps (eg, hernia repair) \\
\hline & Component separation \\
\hline & Burn injuries \\
\hline & Local flaps and adjacent tissue transfers: \\
\hline & Bi-lobe flaps \\
\hline & Propeller flaps \\
\hline & Rhomboid flaps \\
\hline \multirow[t]{9}{*}{ Pedicle flaps } & TRAM flap \\
\hline & VRAM and extended VRAM flaps \\
\hline & Deltopectoral flap \\
\hline & Trapezius flap \\
\hline & Myocutaneous pectoralis flap \\
\hline & Latissimus dorsi flap \\
\hline & Submental flap \\
\hline & Supraclavicular artery flap \\
\hline & Lateral intercostal artery flap \\
\hline \multirow[t]{11}{*}{ Free flaps } & TRAM flap \\
\hline & DIEP flap \\
\hline & SIEA flap \\
\hline & ALT flap \\
\hline & Scapular/parascapular flaps \\
\hline & Submental flap \\
\hline & Fibular flap \\
\hline & DCIA flap \\
\hline & TUG/TMG flap \\
\hline & GAP flap \\
\hline & PAP flap \\
\hline \multirow[t]{2}{*}{ Breast reconstruction } & Implant reconstructions \\
\hline & Tissue expander reconstructions \\
\hline
\end{tabular}

ALT: anterolateral thigh flaps.

DIEP: deep inferior epigastric perforator.

SIEA: superficial inferior epigastric artery

TRAM: transverse abdominus musculocutaneous.

VRAM: vertical rectus abdominus myocutaneous.

$D C I A$ : deep circumflex iliac artery.

TUG/TMG: transverse (myocutaneous) gracilis.

GAP: gluteal artery perforator.

PAP: profunda artery perforator. that Doppler ultrasound may be reliable for estimation of vessel caliber.

It has been suggested that laser-Doppler flowmetry can be used for evaluation of blood flow within flaps. However, when used intraoperatively, it may underestimate flap survival [33]. The technique is also sensitive to small movements and is cumbersome. A recent study reported that although laser Doppler was effective at identifying ischemia in free flaps, it had poor ability to detect perforator vessels [30].

CTA and MRA are often used for preoperative evaluation of perforator vessel location. These methods provide accurate visualization of the anatomic course of vessels through the muscle and fascia [24,34-46]. However, neither provides information regarding blood flow through these vessels, nor the extent of perfusion from the perforator. Information provided by CTA/MRA and intraoperative laser angiography with ICG can be considered complementary; CTA and MRA accurately identify vessel location, whereas ICG provides information regarding the realtime location and extent of perfusion at the level of the skin.

Transcutaneous oxygen monitoring has been shown to improve flap salvage rates when used for postoperative monitoring $[47,48]$. Some investigators have brought this technique into the intraoperative setting, but it can be time consuming and labor intensive for mapping flaps. Initial findings suggest that it may have utility for continuous monitoring of flap perfusion $[49,50]$.

Fluorescein angiography has been used to evaluate tissue perfusion in the operating room. The limitations of fluorescein include a long half-life, rapid leakage from capillaries into the interstitium, and a clearance time of 12 to 18 hours, which precludes re-evaluation during the intraoperative period [22,53-55]. Local ischemia enhances fluorescein diffusion, potentially leading to false-positive results $[53,56]$. Recent data suggest that fluorescein is not as accurate as intraoperative laser angiography, with lower specificity and negative predictive value $[12,21,22,51]$. Toxicity of the contrast medium is also a concern.

\section{Evidence of utility for intraoperative Use of the SPY system}

ICG has been successfully used to evaluate perfusion in ophthalmologic procedures for decades [57,58]. More recently, the technology was adopted for use in cardiac [59,60], vascular [61,62], and transplant surgery [63]. Over the last decade, surgeons have applied the technology to plastic reconstructive surgical procedures, demonstrating clinical utility $[1,11,12,16,22,52]$. 


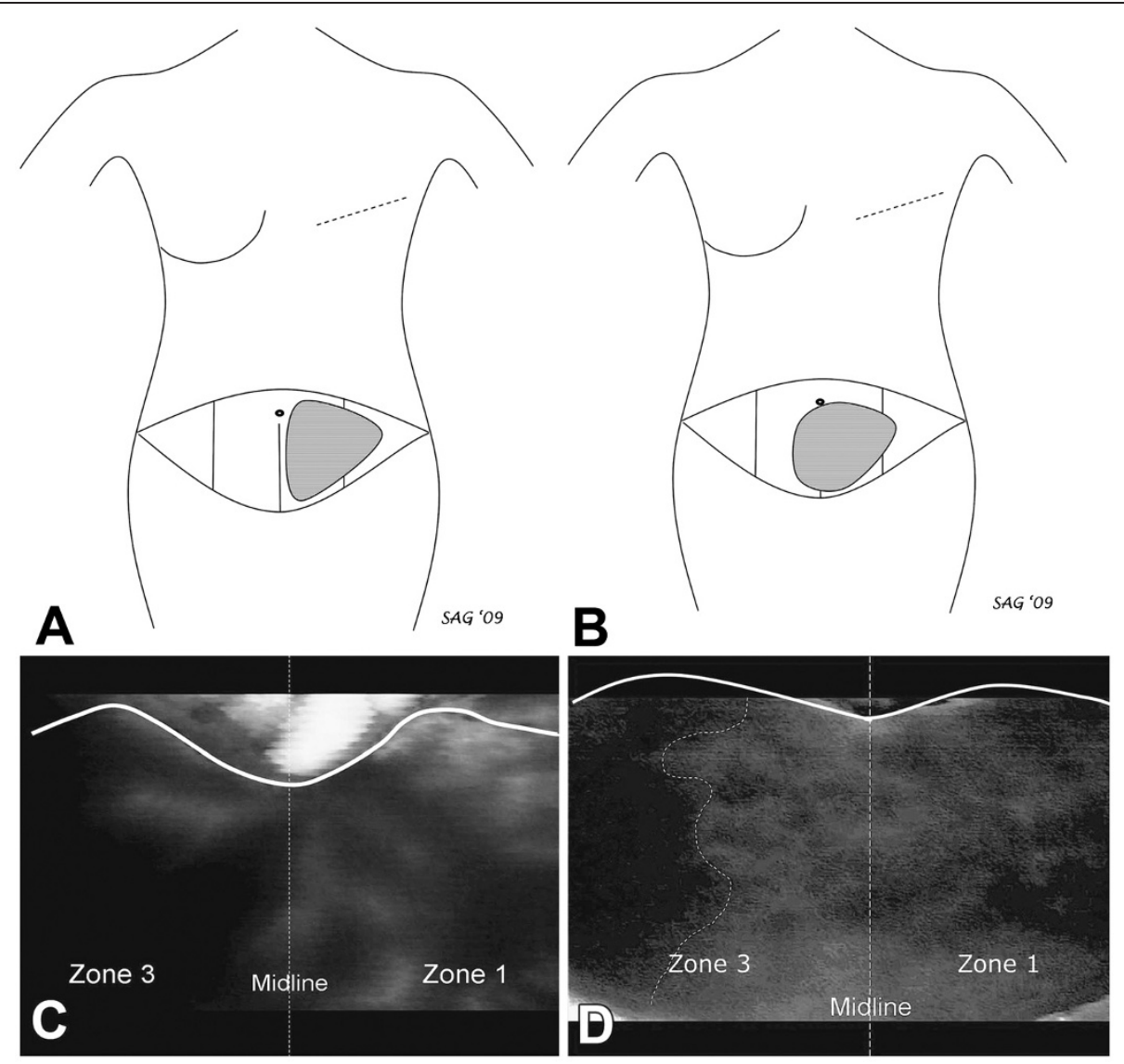

Figure 1 Illustration of the use of SPY to assist in the design of transverse abdominus musculocutaneous (TRAM) flap for breast reconstruction in two patient cases. Panel $\mathbf{A}$ shows a schematic illustration of the best perfused tissue in the TRAM flap for Case 1. This flap was designed based on the corresponding SPY image (Panel $\mathbf{C}$ ), which demonstrated good perfusion in zone 1, clearly definable and in contrast to the poor perfusion across the midline in zone 3. In contrast, Panel B shows the schematic flap design for the TRAM flap in Case 2 based on the SPY image (Panel D), which demonstrated good perfusion in zone 1 and to a clearly definable point in zone 3 (dotted line). Lateral to this point in zone 3 , fluorescence on SPY remained poor, indicating areas of relative ischemia and potential tissue loss. This information was originally published in Can J Plast Surg 2011;19(1):e1-e5.

Use of SPY intraoperative perfusion assessment system in reconstructive surgeries

Clinical experience with intraoperative laser angiography for visualization of tissue perfusion during reconstructive surgical procedures is summarized in Table 2. Studies in reconstructive surgical procedures have reported good correlation between ICG-visualized circulation and postoperative outcomes [13,23,64-66]. In case series and prospective studies, adequate intraoperative perfusion assessment using SPY was associated with reduced rates of postoperative necrosis and flap loss compared to clinical judgment alone in a variety of reconstructive procedures, including free flap, pedicle flap, and implant reconstructions $[1,5,8,11,14,18,20-22,67]$.

\section{Recommendations for the intraoperative Use of SPY}

Using clinical experience and published evidence, the authors developed recommendations for the intraoperative use of the SPY System to assess tissue perfusion in reconstructive surgical procedures. These recommendations are not intended to be prescriptive, but rather, to serve as general principles for the use of the SPY System in the intraoperative evaluation of tissues during reconstructive surgical procedures. The overall principles agreed on by the authors are listed by indication in Table 3. Specific technical recommendations regarding the use of the SPY System are also provided, including dosing of ICG and timing of evaluation (Table 4). A partial list of the types of flaps that may be appropriate for evaluation with SPY is provided in Table 5. The authors' use of SPY in various reconstructive applications is illustrated in Figures 1, 2, 3 and 4 .

\section{Free flaps}

The sequence of steps at which perfusion assessment with ICG for free flaps should be considered is illustrated in Table 3. The surgeon may consider performing 

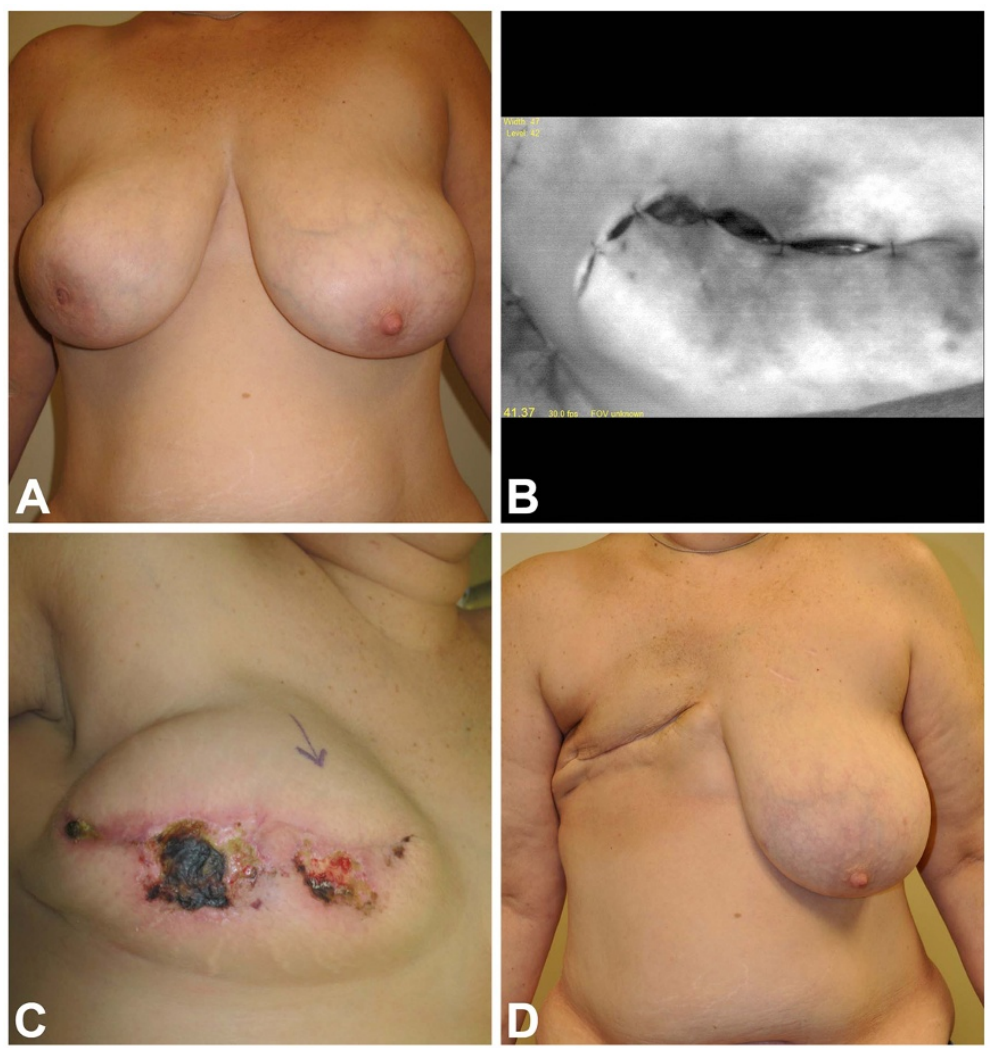

Figure 2 In this case, a 45-year-old woman with right breast cancer (Panel A) requested expander insertion to maintain domain during chemotherapy and radiation therapy prior to autologous conversion. SPY image (Panel B) identified poor perfusion in an extensive area around the incision. Clinically, the skin appeared well perfused and was preserved based on clinical judgment. Postoperative ischemia ensued, leading to full-thickness necrosis (Panel C). Two attempts at salvage with debridement and expander deflation failed to achieve successful closure, and the expander was removed to allow the patient to proceed with chemotherapy and radiation therapy. The resulting healed, radiated mastectomy site prior to free TRAM reconstruction is shown in Panel $\mathbf{D}$.

the technique prior to any manipulation of the donor site to aid in flap design, during harvest of the flap to aid in vessel selection, and after flap elevation to aid in determining which parts of the flap should be used and where they should be positioned.

The pattern of ICG fluorescence can also be used to evaluate venous return. With SPY, venous congestion manifests as an area of brightness that persists for 5 to 20 minutes after administration of ICG. Persistent fluorescence often appears "hyper-white" on the monitor, suggesting that plasma-bound ICG is trapped within the perfusion zone. Re-imaging the flap 5 to 20 minutes after ICG injection can identify venous congestion following dissection, transfer, and/ or inset. Persistent fluorescence in a free flap suggests the presence of venous thrombosis, a kinked vein, or improperly designed flap. With repeated injections of ICG (i.e., $\geq 4$ injections), there may be some residual background fluorescence that must be distinguished from venous congestion.

\section{Pedicle flaps}

For pedicle flaps, the SPY System can be used to identify perforator perfusion zones and optimize design of the skin paddle over the perfusion zone (see Table 3). Once the flap has been designed and elevated, ICG may be administered to confirm viability of the flap prior to transfer and again following inset. After each of these steps, the ICG fluorescence pattern can help to identify problems, such as compressed or kinked vessels in the pedicle, as well as areas of poor perfusion that may require debridement or adjustments to flap inset, such as delay of inset, minimizing postoperative tissue necrosis.

\section{Mastectomy flaps}

Following completion of a mastectomy procedure, the SPY System can help to determine the viability of mastectomy flaps (see Table 3). This information can be used to maximize use of the mastectomy skin, thereby improving aesthetics by minimizing the need for larger 

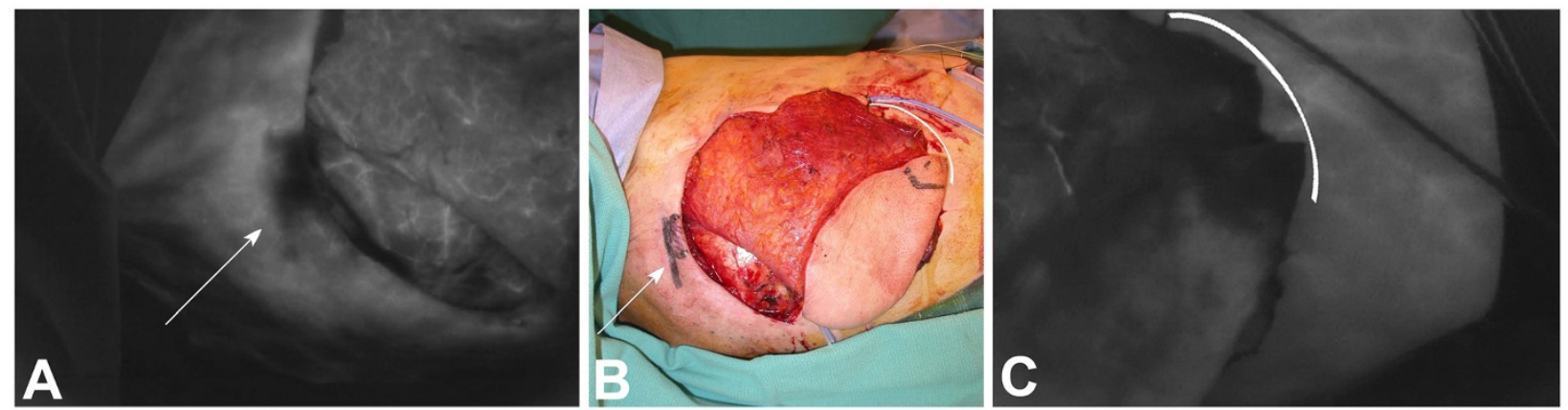

Figure 3 Latissimus dorsi (LAT) flap evaluated using SPY. Necrosis of the tips of transversely oriented LAT flaps can occur in some patients; the use of SPY identifies these regions intraoperatively. Panel A shows a SPY image of a LAT flap (head to the left, legs to the right) following rotation to the chest for breast reconstruction. The image shows two parallel scars from a previous biopsy with evidence of poor blood supply across the scars. This area was resected (arrow). Similarly, Panel $\mathbf{C}$ shows poor perfusion in the tip of the LAT flap and its underlying muscle (bracket). It is assumed that these regions of LAT flaps in some patients are outside the primary angiosome of the thoracodorsal artery and are supplied by smaller vessels that are divided in the normal harvest of the flap. In both cases, the tissues look perfectly normal clinically (Panel B, arrow and bracket). Each of these regions should be debrided prior to use in reconstruction. As illustrated by this case, variable anatomy can lead to areas of poor perfusion, despite good flap design and excellent surgical technique, that can only be identified through intraoperative imaging.

skin paddles from transferred flaps and minimizing scar burden.

\section{Implant reconstruction}

The SPY System can provide information about the effects of tension and pressure on perfusion in the mastectomy flap, which may help to inform decisions regarding immediate implant placement or expander inflation volume. When tissue expanders are used, the effect of expander volume on skin flap perfusion can be monitored in real time, and decisions can be made regarding appropriate intraoperative fill volumes $[1,13,68]$. A final image may be obtained to confirm adequate flap perfusion following modification to the expander, implant, or skin.
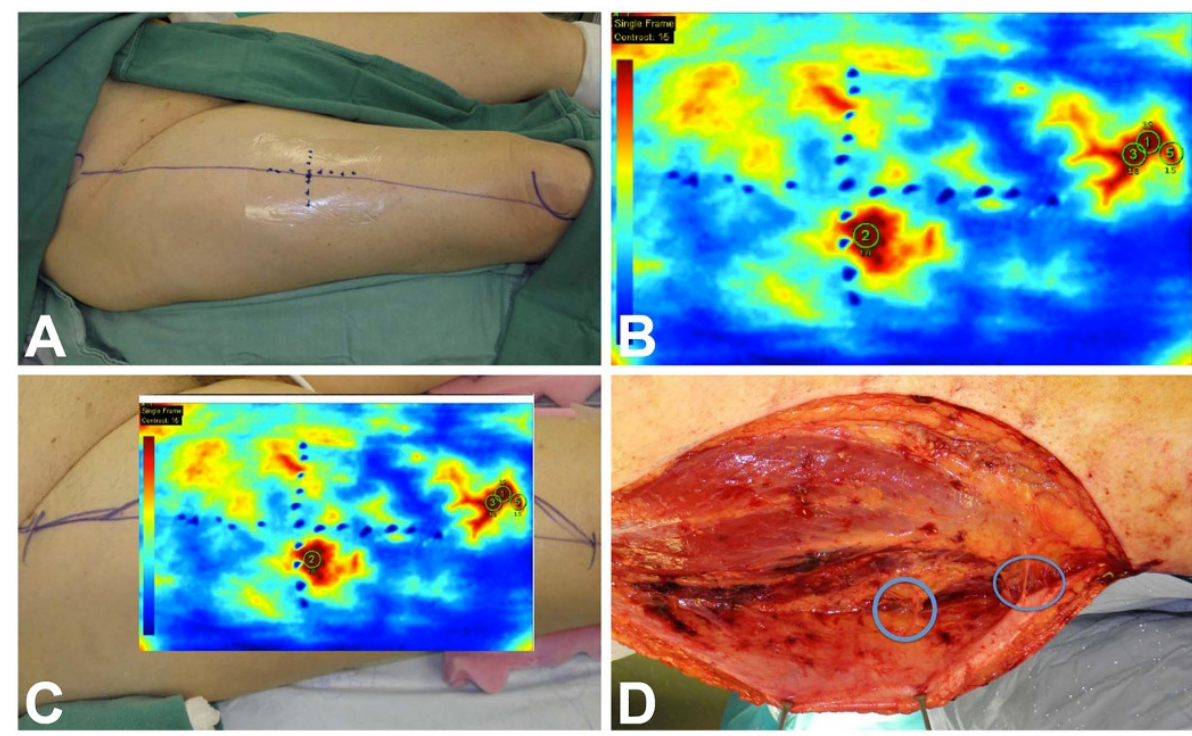

Figure 4 Illustration of the use of SPY to optimize placement of skin paddle for harvest of the anterolateral thigh (ALT) flap for reconstructive surgery. The proposed center of the ALT flap, in the right thigh, is marked in standard fashion at the midpoint of a line drawn between the anterior superior iliac spine $(\mathbf{A})$ and the lateral patella $(P)$ in preparation for harvest (Panel $\mathbf{A}$ ). The colorized SPY $\mathrm{Q}$ analysis, shown in Panel B, identifies perforator perfusion zones in red along the AP line axis. The color SPY image is transposed over the native thigh in Panel $\mathbf{C}$, showing the locations of perforator perfusion zones. Partial elevation of the ALT flap (Panel D) shows perforators (circled) emanating from the vastus lateralis muscle and rectus femoris muscle, corresponding to the perforator perfusion zones identified by SPY in Panels B and C. SPY will often show significant variation in perforator location, exposing the weakness of standard flap design. 


\section{Skin-sparing and nipple-sparing procedures}

The SPY System can be used to evaluate perfusion of the mastectomy skin and the nipple-areolar complex (NAC) during a skin-sparing, nipple-sparing mastectomy. After completion of mastectomy, the NAC can be evaluated by examining both its superficial and deep surfaces to help determine whether the NAC should be retained. By examining the NAC with a sizer in place, the SPY System can aid in the decision to go straight to implant or to perform a staged reconstruction, minimizing risk of necrosis in the areas at risk.

\section{Other skin flaps}

Intraoperative laser angiography can be utilized to evaluate perfusion in multiple types of skin flaps (see Table 5 for examples). Imaging can be performed prior to incision to evaluate perfusion in the donor site and design the flap, during flap elevation to select the number and location of perforating vessels, following dissection to confirm viability of the flap, and again after transfer and after inset to confirm perfusion and rule out compression or kinking that may have occurred after flap transfer. Improved perfusion assessment can also assist in the decision to delay reconstruction, if perfusion is determined to be inadequate.

\section{Benefits in challenging morphologies}

In the authors' experience, intraoperative laser angiography has particular clinical utility in cases where clinical judgment may be challenging, such as patients with darker skin tones and/or severe bruising or other tissue damage. Pigmentation or discoloration of the skin interfere with clinical assessment but are transparent to the SPY system. Perfusion across scars can also be visualized using SPY technology, whereas clinical assessment may be of limited utility.

\section{Amount and timing of ICG administration and coordination with image capture}

The recommendations include specific guidance regarding the method and timing of ICG administration, the timing of image capture with the SPY System, and the use of repeat evaluations during the same procedure (see Table 4). ICG is administered via intravenous bolus, using the best available venous access (central or peripheral), followed by a $10 \mathrm{cc}$ bolus of normal saline.

Positioning the SPY device, injecting the ICG, and capturing the images requires coordination between surgeon and anesthesiologist to ensure that useful images are acquired. Surgeons should ensure that the SPY camera is on and recording before the first blush of fluorescence is seen. Newer versions of the SPY System include a 5-second buffer whenever the camera is on; therefore, images will be captured from 5 seconds prior to initiation of recording.
The maximum capture time is 4.5 minutes, but additional scans may be performed immediately after this period, extending the study without additional injection of ICG [15].

\section{Special considerations}

Factors that may affect the use of the SPY System are listed in Table 6. Characteristics associated with ischemia (eg, smoking and peripheral vascular disease) may lead to reduced fluorescence and longer wait times following administration of ICG. Dyes, such as methylene blue, can interfere with the fluorescent image. Vasoconstrictors, such as epinephrine, drastically diminish blood flow and preclude accurate estimation of normal tissue perfusion.

The SPY-Q Analysis Toolkit companion software allows for quantification of perfusion by assigning numeric values to intensity of fluorescence. Two types of values can be used: relative and absolute. Relative values are normalized to a reference value based on an image taken from tissue outside the area of interest, but within the field of view. Absolute values pertain strictly to the intensity of fluorescence signal in any given image. In the opinion of the authors, and based on the currently available technology, absolute values may have greater utility for quantification of perfusion than relative values, which depend on an arbitrary reference image from an area of normal perfusion. The utility of these values for prediction of necrosis remains to be determined. An analysis of images from a study of breast reconstruction using this software [12] suggested that quantification using absolute values may be useful to stratify tissue perfusion into three categories: viable tissue, tissue at high risk for necrosis, and tissue that should be evaluated in correlation to other clinical

Table 6 Variables that may impact use of modalities to evaluate tissue perfusion

\begin{tabular}{|c|c|}
\hline \multirow[t]{8}{*}{ Characteristics associated with ischemia } & Previous radiation treatment \\
\hline & Previous or aggressive surgery* \\
\hline & Current smoking \\
\hline & Obesity \\
\hline & Diabetes \\
\hline & Vasculopathy \\
\hline & Chronic corticosteroid use \\
\hline & Thin mastectomy flaps \\
\hline \multirow{2}{*}{$\begin{array}{l}\text { Agents that interfere with imaging } \\
\text { techniques }\end{array}$} & Methylene blue \\
\hline & Lymphazurin blue \\
\hline Agents that affect blood flow & $\begin{array}{l}\text { Vasoconstrictors } \\
\text { (eg, epinephrine) }^{* *}\end{array}$ \\
\hline \multicolumn{2}{|c|}{$\begin{array}{l}\text { *Previous incisions may affect blood flow; ICG perfusion assessment may be of } \\
\text { particular utility for detection of perfusion across scars. } \\
\text { **Vasopressors affect all methods of estimation of perfusion in tissue. } \\
\text { Diminished blood flow following administration of epinephrine may indicate } \\
\text { the need to wait } \geq 2 \text { hours for accurate ICG imaging. A negative result on ICG } \\
\text { perfusion assessment may indicate the need to wait longer for recovery of } \\
\text { perfusion. }\end{array}$} \\
\hline
\end{tabular}


factors. Future studies may further clarify the roles for these values in prediction of postoperative complications.

Other factors that should be considered when using the SPY System include turning off ambient lighting to improve fluorescent image viewing (and on for visible photography), positioning the camera head perpendicular to the body surface being imaged, ensuring the patient is normothermic and normotensive, and administering ICG through the largest available intravenous access.

\section{Safety of ICG}

ICG has an excellent safety profile, with an adverse event rate of approximately 1 in 42,000 patients [69,70]. Anaphylactic reactions are rare, but can occur in patients with iodine sensitivity. The recommended maximum dose of ICG is $2 \mathrm{mg} / \mathrm{kg}$ [15].

\section{Summary}

The elevation of tissue of any type results in potential devascularization and the risk for vascular compromise. The use of simple, reliable, and accurate adjunctive modalities to assist the surgeon in determining vascular compromise or poor perfusion will provide surgeons the opportunity to intervene early and minimize risk for postoperative complications.

The SPY Intraoperative Perfusion Assessment System has clinical utility for the perioperative visualization of tissue perfusion in multiple settings. The authors propose recommendations regarding the applications and most effective use of this technology for a range of plastic and reconstructive procedures. As this technology is more widely adopted and studied in the reconstructive setting, refinements to these technique recommendations may be made.

\section{Competing interests}

Funding for the consensus development process was provided by LifeCell

Corporation, Branchburg, NJ.

Dr. Geoffrey C. Gurtner is a consultant for LifeCell Corp.

Dr. Glyn E. Jones is a consultant for LifeCell Corp.

Dr. Peter C. Neligan has nothing to disclose.

Dr. Martin I. Newman is a consultant for LifeCell Corp.

Dr. Brett T. Phillips has nothing to disclose.

Dr. Justin M. Sacks is a consultant/speaker for LifeCell Corp.

Dr. Michael R. Zenn is a consultant for LifeCell Corp and Novadaq

Technologies.

\section{Authors' contributions}

All authors contributed to the conception of the work and participated in the design and review of the manuscript.

\section{Products discussed}

SPY ${ }^{\circledR}$ Intraoperative Perfusion Assessment System (distributed in North America by LifeCell Corp., Branchburg, NJ; manufactured by Novadaq Technologies Inc., Richmond, British Columbia, Canada).

\section{Acknowledgements}

Editorial and writing support was provided by Joshua Kilbridge of Kilbridge Associates, San Francisco, CA.

\section{Author details}

'Stanford Hospital and Clinics, Palo Alto, CA, USA. ${ }^{2}$ Peoria Surgical Group, Peoria, IL, USA. ${ }^{3}$ University of Washington Medical Center, Seattle, WA, USA. ${ }^{4}$ Cleveland Clinic Florida, Westin, FL, USA. ${ }^{5}$ Stony Brook Medical Center, Stony Brook, NY, USA. ${ }^{6} J o h n s$ Hopkins School of Medicine, Baltimore, MD, USA.

${ }^{7}$ Plastic and Reconstructive Surgery, Duke University Medical Center, Durham, NC, USA.

Received: 15 October 2012 Accepted: 14 December 2012

Published: 7 January 2013

\section{References}

1. Komorowska-Timek E, Gurtner GC: Intraoperative perfusion mapping with laser-assisted indocyanine green imaging can predict and prevent complications in immediate breast reconstruction. Plast Reconstr Surg 2010, 125:1065-1073.

2. Kubo T, Yano K, Hosokawa K: Management of flaps with compromised venous outflow in head and neck microsurgical reconstruction. Microsurgery 2002, 22:391-395.

3. Garvey PB, Buchel EW, Pockaj BA, Casey W Jr, Gray RJ, Hernandez JL, Samson TD: DIEP and pedicled TRAM flaps: a comparison of outcomes. Plast Reconstr Surg 2006, 117:1711-1719.

4. Spear SL, Ducic I, Cuoco F, Hannan C: The effect of smoking on flap and donor-site complications in pedicled TRAM breast reconstruction. Plast Reconstr Surg 2005, 116:1873-1880.

5. Pestana IA, Coan B, Erdmann D, Marcus J, Levin LS, Zenn MR: Early experience with fluorescent angiography in free-tissue transfer reconstruction. Plast Reconstr Surg 2009, 123:1239-1244.

6. Newman MI, Samson MC, Tamburrino JF, Swartz KA, Brunworth L: An investigation of the application of laser-assisted indocyanine green fluorescent dye angiography in pedicle transverse rectus abdominus myocutaneous breast reconstruction. Can J Plast Surg 2011, 19:e1-e5.

7. Jallali N, Ridha H, Butler PE: Postoperative monitoring of free flaps in UK plastic surgery units. Microsurgery 2005, 25:469-472.

8. Mothes H, Donicke T, Friedel R, Simon M, Markgraf E, Bach O: Indocyanine-green fluorescence video angiography used clinically to evaluate tissue perfusion in microsurgery. J Trauma 2004, 57:1018-1024.

9. Olivier WA, Hazen A, Levine JP, Soltanian H, Chung S, Gurtner GC: Reliable assessment of skin flap viability using orthogonal polarization imaging. Plast Reconstr Surg 2003, 112:547-555.

10. Tan BK, Newman Ml, Swartz KA, Samson MC: Subfascial perforator dissection for DIEP flap harvest. Plast Reconstr Surg 2009, 124:1001-1002.

11. Newman MI, Samson MC: The application of laser-assisted indocyanine green fluorescent dye angiography in microsurgical breast reconstruction. J Reconstr Microsurg 2009, 25:21-26.

12. Phillips BT, Lanier ST, Conkling N, Wang ED, Dagum AB, Ganz JC, Khan SU, Bui DT: Intraoperative perfusion techniques can accurately predict mastectomy skin flap necrosis in breast reconstruction: results of a prospective trial. Plast Reconstr Surg 2012, 129:778e-788e.

13. Giunta RE, Holzbach T, Taskov C, Holm PS, Brill T, Busch R, Gansbacher B, Biemer E: Prediction of flap necrosis with laser induced indocyanine green fluorescence in a rat model. Br J Plast Surg 2005, 58:695-701.

14. Jones GE, Garcia CA, Murray J, Elwood ET, Whitty LA: Fluorescent intraoperative tissue angiography for the evaluation of the viability of pedicled TRAM flaps. Plast Reconstr Surg 2009, 124:53.

15. Elite System SPY: Kit instructions for use. Branchburg, NJ: LifeCell Corp; 2011.

16. Murray JD, Jones GE, Elwood ET, Whitty LA, Garcia C: Fluorescent intraoperative tissue angiography with indocyanine green: evaluation of nipple-areola vascularity during breast reduction surgery. Plast Reconstr Surg 2010, 126:33e-34e.

17. Tamburrino JF, Newman MI, Samson MC, Swartz KA: Laser-assisted indocyanine green fluorescent dye angiography (LA-ICG) in evaluation of mastectomy flaps, Presented at: 2010 annual meeting for AAHS, ASPN, and ASRM. Florida: Boca Raton; 2010.

18. Azuma R, Morimoto Y, Masumoto K, Nambu M, Takikawa M, Yanagibayashi S, Yamamoto N, Kikuchi M, Kiyosawa T: Detection of skin perforators by indocyanine green fluorescence nearly infrared angiography. Plast Reconstr Surg 2008, 122:1062-1067.

19. Prantl L, Schmitt S, Gais S, Tsui TY, Lamby P, Babilas P, Nerlich M, Kubale R, Zorger N, Herold T, et al: Contrast harmonic ultrasound and indocyaninegreen fluorescence video angiography for evaluation of dermal and 
subdermal microcirculation in free parascapular flaps. Clin Hemorheol Microcirc 2008, 38:31-44.

20. De Lorenzi F, Yamaguchi S, Petit JY, Rietjens M, Garusi C, Martella S, Rey PC, Gennari R: Evaluation of skin perfusion after nipple-sparing mastectomy by indocyanine green dye. Preliminary results. J Exp Clin Cancer Res 2005 24:347-354.

21. Holm C, Tegeler J, Mayr M, Becker A, Pfeiffer UJ, Muhlbauer W: Monitoring free flaps using laser-induced fluorescence of indocyanine green: a preliminary experience. Microsurgery 2002, 22:278-287.

22. Holm C, Mayr M, Hofter E, Becker A, Pfeiffer UJ, Muhlbauer W: Intraoperative evaluation of skin-flap viability using laser-induced fluorescence of indocyanine green. Br J Plast Surg 2002, 55:635-644.

23. Still J, Law E, Dawson J, Bracci S, Island T, Holtz J: Evaluation of the circulation of reconstructive flaps using laser-induced fluorescence of indocyanine green. Ann Plast Surg 1999, 42:266-274.

24. Rozen WM, Phillips TJ, Ashton MW, Stella DL, Gibson RN, Taylor Gl: Preoperative imaging for DIEA perforator flaps: a comparative study of computed tomographic angiography and doppler ultrasound. Plast Reconstr Surg 2008, 121:1-8.

25. Khalid AN, Quraishi SA, Zang WA, Chadwick JL, Stack BCJ: Color doppler ultrasonography is a reliable predictor of free tissue transfer outcomes in head and neck reconstruction. Otolaryng Head Neck 2006, 134:635-638.

26. Giunta RE, Geisweid A, Feller AM: The value of preoperative Doppler sonography for planning free perforator flaps. Plast Reconstr Surg 2000, 105:2381-2386.

27. Hallock GG: Doppler sonography and color duplex imaging for planning a perforator flap. Clin Plast Surg 2003, 30:347-357.

28. Blondeel PN, Beyens G, Verhaeghe R, Van Landuyt K, Tonnard P, Monstrey SJ, Matton G: Doppler flowmetry in the planning of perforator flaps. $\mathrm{Br} J$ Plast Surg 1998, 51:202-209.

29. Yu P, Youssef A: Efficacy of the handheld Doppler in preoperative identification of the cutaneous perforators in the anterolateral thigh flap. Plast Reconstr Surg 2006, 118:928-933. discussion 934-925.

30. Schlosser S, Wirth R, Plock JA, Serov A, Banic A, Erni D: Application of a new laser Doppler imaging system in planning and monitoring of surgical flaps. J Biomed Opt 2010, 15:036023.

31. Holzle F, Loeffelbein DJ, Nolte D, Wolff KD: Free flap monitoring using simultaneous non-invasive laser Doppler flowmetry and tissue spectrophotometry. J Craniomaxillofac Surg 2006, 34:25-33.

32. Heller L, Levin LS, Klitzman B: Laser Doppler flowmeter monitoring of freetissue transfers: blood flow in normal and complicated cases. Plast Reconstr Surg 2001, 107:1739-1745.

33. Heden P, Jurell G, Arnander C: Prediction of skin flap necrosis: a comparative study between laser Doppler flowmetry and fluorescein test in a rat model. Ann Plast Surg 1986, 17:485-488.

34. Ghattaura A, Henton J, Jallali N, Rajapakse Y, Savidge C, Allen S, Searle AE, Harris PA, James SE: One hundred cases of abdominal-based free flaps in breast reconstruction. The impact of preoperative computed tomographic angiography. JPRAS 2010, 63:1597-1601.

35. Smit JM, Dimopoulou A, Liss AG, Zeebregts CJ, Kildal M, Whitaker IS, Magnusson A, Acosta R: Preoperative CT angiography reduces surgery time in perforator flap reconstruction. JPRAS 2009, 62:1112-1117.

36. Cina A, Salgarello M, Barone-Adesi L, Rinaldi $P$, Bonomo L: Planning breast reconstruction with deep inferior epigastric artery perforating vessels: multidetector CT angiography versus color Doppler US. Radiology 2010, 255:979-987.

37. Scott JR, Liu D, Said H, Neligan PC, Mathes DW: Computed tomographic angiography in planning abdomen-based microsurgical breast reconstruction: a comparison with color duplex ultrasound. Plast Reconstr Surg 2010, 125:446-453.

38. Phillips TJ, Stella DL, Rozen WM, Ashton M, Taylor Gl: Abdominal wall CT angiography: a detailed account of a newly established preoperative imaging technique. Radiology 2008, 249:32-44.

39. Rosson GD, Williams CG, Fishman EK, Singh NK: 3D CT angiography of abdominal wall vascular perforators to plan DIEAP flaps. Microsurgery 2007, 27:641-646.

40. Masia J, Clavero JA, Larranaga JR, Alomar X, Pons G, Serret P: Multidetectorrow computed tomography in the planning of abdominal perforator flaps. JPRAS 2006, 59:594-599.

41. Chernyak V, Rozenblit AM, Greenspun DT, Levine JL, Milikow DL, Chia FA, Erhard HA: Breast reconstruction with deep inferior epigastric artery perforator flap: 3.0-T gadolinium-enhanced MR imaging for preoperative localization of abdominal wall perforators. Radiology 2009, 250:417-424.

42. Schaverien MV, Ludman CN, Neil-Dwyer J, Perks GB, Akhtar N, Rodrigues JN, Benetatos K, Raurell A, Rasheed T, McCulley SJ: Contrast-enhanced magnetic resonance angiography for preoperative imaging in DIEP flap breast reconstruction. Plast Reconstr Surg 2011, 128:56-62.

43. Newman TM, Vasile J, Levine JL, Greenspun DT, Allen RJ, Chao MT, Winchester PA, Prince MR: Perforator flap magnetic resonance angiography for reconstructive breast surgery: a review of 25 deep inferior epigastric and gluteal perforator artery flap patients. J Magn Reson Imaging 2010, 31:1176-1184.

44. Neil-Dwyer JG, Ludman CN, Schaverien M, McCulley SJ, Perks AG: Magnetic resonance angiography in preoperative planning of deep inferior epigastric artery perforator flaps. JPRAS 2009, 62:1661-1665.

45. Greenspun D, Vasile J, Levine JL, Erhard H, Studinger R, Chernyak V, Newman T, Prince M, Allen RJ: Anatomic imaging of abdominal perforator flaps without ionizing radiation: seeing is believing with magnetic resonance imaging angiography. J Reconstruc Microsurgery 2010, 26:37-44.

46. Rozen WM, Stella DL, Bowden J, Taylor GI, Ashton MW: Advances in the pre-operative planning of deep inferior epigastric artery perforator flaps: magnetic resonance angiography. Microsurgery 2009, 29:119-123.

47. Steele MH: Three-year experience using near infrared spectroscopy tissue oximetry monitoring of free tissue transfers. Ann Plast Surg 2011, 66:540-545

48. Lin SJ, Nguyen MD, Chen C, Colakoglu S, Curtis MS, Tobias AM, Lee BT: Tissue oximetry monitoring in microsurgical breast reconstruction decreases flap loss and improves rate of flap salvage. Plast Reconstr Surg 2011, 127:1080-1085.

49. Keller A: A new diagnostic algorithm for early prediction of vascular compromise in 208 microsurgical flaps using tissue oxygen saturation measurements. Ann Plast Surg 2009, 62:538-543.

50. Keller A: Noninvasive tissue oximetry for flap monitoring: an initial study. J Reconstr Microsurg 2007, 23:189-197.

51. Losken A, Styblo TM, Schaefer TG, Carlson GW: The use of fluorescein dye as a predictor of mastectomy skin flap viability following autologous tissue reconstruction. Ann Plast Surg 2008, 61:24-29.

52. Francisco BS, Kerr-Valentic MA, Agarwal JP: Laser-assisted indocyanine green angiography and DIEP breast reconstruction. Plast Reconstr Surg 2010, 125:116e-118e.

53. Rubben A, Eren S, Krein R, Younossi H, Bohler U, Wienert V: Infrared videoangiofluorography of the skin with indocyanine green-rat random cutaneous flap model and results in man. Microvasc Res 1994, 47:240-251.

54. Singer R, Lewis CM, Franklin JD, Lynch JB: Fluorescein test for prediction of flap viability during breast reconstructions. Plast Reconstr Surg 1978, 61:371-375

55. Jones BM: Monitors for the cutaneous microcirculation. Plast Reconstr Surg 1984, 73:843-850

56. May JWJ, Chait LA, O'Brien BM, Hurley JV: The no-reflow phenomenon in experimental free flaps. Plast Reconstr Surg 1978, 61:256-267.

57. Flower RW, Hochheimer BF: A clinical technique and apparatus for simultaneous angiography of the separate retinal and choroidal circulations. Invest Ophthalmol 1973, 12:248-261.

58. Dzurinko VL, Gurwood AS, Price JR: Intravenous and indocyanine green angiography. Optometry 2004, 75:743-755.

59. Desai ND, Miwa S, Kodama D, Koyama T, Cohen G, Pelletier MP, Cohen EA, Christakis GT, Goldman BS, Fremes SE: A randomized comparison of intraoperative indocyanine green angiography and transit-time flow measurement to detect technical errors in coronary bypass grafts. J Thorac Cardiovasc Surg 2006, 132:585-594.

60. Reuthebuch O, Haussler A, Genoni M, Tavakoli R, Odavic D, Kadner A, Turina M: Novadaq SPY: intraoperative quality assessment in off-pump coronary artery bypass grafting. Chest 2004, 125:418-424

61. Kang Y, Lee J, Kwon K, Choi C: Dynamic fluorescence imaging of indocyanine green for reliable and sensitive diagnosis of peripheral vascular insufficiency. Microvasc Res 2010, 80:552-555.

62. Kang Y, Lee J, Kwon K, Choi C: Application of novel dynamic optical imaging for evaluation of peripheral tissue perfusion. Int J Cardio/ 2010, 145:e99-e101.

63. Sekijima M, Tojimbara T, Sato S, Nakamura M, Kawase T, Kai K, Urashima Y, Nakajima I, Fuchinoue S, Teraoka S: An intraoperative fluorescent imaging system in organ transplantation. Transplant Proc 2004, 36:2188-2190. 
64. Eren S, Rubben A, Krein R, Larkin G, Hettich R: Assessment of microcirculation of an axial skin flap using indocyanine green fluorescence angiography. Plast Reconstr Surg 1995, 96:1636-1649.

65. Matsui A, Lee BT, Winer JH, Laurence RG, Frangioni JV: Predictive capability of near-infrared fluorescence angiography in submental perforator flap survival. Plast Reconstr Surg 2010, 126:1518-1527.

66. Matsui A, Lee BT, Winer JH, Laurence RG, Frangioni JV: Quantitative assessment of perfusion and vascular compromise in perforator flaps using a near-infrared fluorescence-guided imaging system. Plast Reconstr Surg 2009, 124:451-460.

67. Yamaguchi S, De Lorenzi F, Petit JY, Rietjens M, Garusi C, Giraldo A, Rey PC, Urban C, Martella S, Bosco R: The "perfusion map" of the unipedicled TRAM flap to reduce postoperative partial necrosis. Ann Plast Surg 2004, 53:205-209.

68. Graham BH, Walton RL, Elings VB, Lewis FR: Surface quantification of injected fluorescein as a predictor of flap viability. Plast Reconstr Surg 1983, 71:826-833.

69. Benya R, Quintana J, Brundage B: Adverse reactions to indocyanine green: a case report and a review of the literature. Cathet Cardiovasc Diagn 1989, 17:231-233.

70. Hope-Ross M, Yannuzzi LA, Gragoudas ES, Guyer DR, Slakter JS, Sorenson JA, Krupsky S, Orlock DA, Puliafito CA: Adverse reactions due to indocyanine green. Ophthalmology 1994, 101:529-533.

doi:10.1186/1750-1164-7-1

Cite this article as: Gurtner et al.: Intraoperative laser angiography using the SPY system: review of the literature and recommendations for use. Annals of Surgical Innovation and Research 2013 7:1.

\section{Submit your next manuscript to BioMed Central and take full advantage of:}

- Convenient online submission

- Thorough peer review

- No space constraints or color figure charges

- Immediate publication on acceptance

- Inclusion in PubMed, CAS, Scopus and Google Scholar

- Research which is freely available for redistribution 